\title{
Banished to a Greek island
}

\author{
Rosalind RAmsay, Registrar in Psychiatry, University College and Middlesex School \\ of Medicine, London W1N 8AA
}

In October, public attention focused on psychiatrists gathering for the Eighth World Congress in Athens. Was psychiatry still being abused for political purposes in the Soviet Union (Bloch, 1990)? And were mental patients elsewhere being mistreated? At the Stadium of Peace and Friendship overlooking the Aegean Sea, delegates had the chance to meet and talk about these important issues concerning human rights and human dignity.

Perhaps the most animated discussions centred on the outrage surrounding the nearby island of Leros, which hit the British public in September. Writing in the Observer, journalist John Merritt revealed the "hidden scandal" of this Greek island which, only an hour's flight from Athens is used "as a dumping ground for those the world wishes to forget" (Merritt, 1989).

The Colony of Mentally Ill on Leros was established just over 30 years ago, taking over the extensive military installations left on the island by the Italians from the Second World War. It soon expanded, accepting hundreds of patients from overcrowded institutions in Athens and Thessaloniki. By 1970, following further large 'transportations' of patients from mainland Greece there were over 2,000 inmates. However, the number of trained staff to care for the growing patient population remained unchanged. Director of the women's unit, Dr Katherina Karanikolas, would have welcomed additional assistance in her work, but explained that most Greek psychiatrists were reluctant to isolate themselves on a small island. Instead, the handful of trained doctors and nurses relied increasingly on local help in patient management.

Throughout this time over the last 30 years, Greece has been in a state of political turmoil, facing complex social and economic problems. Fifteen years ago the Generals were overthrown and a democratic government installed. Soon afterwards, the country applied to join the European Community. In the rest of Greece psychiatrists faced problems in their work similar to those on Leros resulting from the inadequate provision for mental health care. Unfortunately, Greek political leaders failed to ask for help with developing the country's mental health services, so that this troublesome area was not included in the Treaty of Rome in 1979. Yet, the European Social Fund was later able to respond to requests for assistance. In 1983 a commission of European medical experts and economists was formed in Brussels to advise the EC on reform of the Greek psychiatric sector.

The commission visited Leros. British economist Alan Maynard recalls, "The island was like a prison; the sentence was life, and at death the patient's fate was to be loaded on to the back of a lorry and buried in an unmarked plot" (Maynard 1989). There appeared to be no trained staff and no management of any consequence. Although Leros was "the most frightful experience", there were equally disturbing conditions in other facilities in Thessaloniki and Daphni and on Corfu. Altogether these facilities contained almost 10,000 lost souls.

The team proposed stopping the flow of new patients into such 'bins' as well as training staff and providing community care so that current inmates would have the chance to leave. It devised programmes for each site over a four-year period with funding coming from the European tax payer and the Greek government. Irish psychiatrist Professor Ivor Browne emphasised the importance of having Greek-led intervention. Leros posed some unique problems as a small island where many of the locals were heavily dependent on the hospital for their livelihood. The commission suggested a special economic programme for the island as a whole. Over the following couple of years it also recommended sending a number of medical task forces with staff coming from Ireland, Italy and the Netherlands to work with local psychiatrists on Leros.

In 1986, news about Leros (Ekdawi, 1987) alerted the attention of Dr Nick Bouras, a Greek psychiatrist now working in London. Colleagues in Athens were keen to involve him in their work. After waiting over a year he finally obtained permission from the Greek authorities to visit the island. Meanwhile, health officials in Athens were co-opting local psychiatrists, including Dr George Papageorgiou, to work there. Bouras and Papageorgiou were both shocked by the state of mute, nude and deeply regressed patients; they began a detailed survey to get more factual information on them. Using an adapted form of the Community Placement Questionnaire they assessed patients' level of dependency as a first step to preparing for their care in the community (Bouras et al, in press). 
In 1988 there were 1,200 patients on Leros. Their mean age was 54 years and over two-thirds were men; $84 \%$ had come from other hospitals and the majority had been on the island for at least 20 years. Fifty-five per cent were psychotic, a high proportion had mental handicap while fewer had significant physical handicap. Almost half were on no drug therapy. A few had no apparent mental illness. Eighty-one per cent had no contact with their families. The team were clearly dealing with a highly disadvantaged group of isolated chronic patients. However, staff suggested $36 \%$ of them could live outside the hospital while researchers put this figure even higher, estimating $46 \%$ of the inmates could live independently or in sheltered accommodation.

Now staff have begun to improve basic living conditions. Starting on notorious Ward 16, they have moved some of the 135 patients into small villas so that they can "look at each of them as a person, not as a collection of symptoms". Patients are relearning forgotten social and daily living skills. The hospital is at last starting to change. Papageorgiou has been keen to engage the support of islanders working in the institution and tried setting up sensitivity groups for them as well as providing an informal teaching programme.

In other parts of Greece similar moves are occurring. Community mental health centres are opening and psychiatric clinics are being set up in general hospitals. The role of the old long-stay mental institutions is less clear.

Commission psychiatrist Ivor Browne suggests the original timeframe for reforms in mental health services in Greece was perhaps unrealistic, given that other European countries have been grappling with moves into the community for the past 30 years. The Greek government's sluggishness in spending EC money on community mental health is an indication of this. By 1988 they had spent less than a third of the EC grant from four years earlier and had to ask for the project to be extended. Browne stresses the need for the Greek government to develop a global mental health strategy to implement changes while allowing local groups the autonomy to put plans into action. At present, medical staff are hindered by the constant changes in government, discontinuity in leadership leading to lack of central planning. Unfortunately, the central administration is unwilling to relinquish any power so that the decision making process has seized up. As Browne points out, foreign advisers provide an added impetus, but overall responsibility remains in Greek hands.
Foreign delegates attending the Athens meeting were moved by the plight of patients on Leros and in some of the other Greek hospitals. They called for a motion to the Greek government expressing their concern, recognising that although an excellent start has been made in some areas, there was still an urgent need to continue and expand these projects forming a fully fledged mental health service throughout the country. Resources were essential to provide adequate managerial structures at local and central levels. Only by developing a comprehensive community based mental health service will the old institutions such as Leros become obsolete.

Away from Athens, debate about how to help the Greeks provide more humanitarian care for their chronically institutionalised patients continues. Leros is emerging as an important symbol expressing the dissatisfaction felt over the predicament of mentally ill people throughout the world. Four weeks after the WPA Congress, members of the Society for Greek Studies in London discussed the challenge of Leros. The institution raises not only practical issues but psychological ones too. By the process of 'islandisation', people are physically isolated, while psychologically, the mad can be contained and forgotten within a compartment or island in the human psyche. Successful 'de-islandisation' demands greater acceptance of deviant behaviour.

In a wider context, the rest of Europe and the United States have faced tremendous hurdles developing care for their mentally sick, interrupted by brief periods of optimism when significant progress seemed to be happening, most recently in the 1960 s with the first tentative moves from hospital to community based care. Yet there are still major problems with new systems of care established over the last 30 years. It will be essential to help the Greeks benefit from lessons hard learnt elsewhere.

\section{References}

BLoch, S. (1990) Athens and Beyond: Soviet psychiatric abuse and the WPA. Psychiatric Bulletin, 14, 129-133.

BOURAs, N., CLIFFORD, P.\& WEBB, Y. (eds). De-institutionalisation and Patients' Needs Assessment: The Leros Challenge. London: NUPRD. (in press).

EkDAW, M.Y. (1987) Asylum of Leros (letter). Psychiatric Bulletin, 11, 275.

MAYNARD, A. (1989) Misery of lost souls on holiday island. Health Service Journal, 99, 1213.

MERRIT, J. (1989) Europe's guilty secret. Observer, 10 September, 1, 17. 